\title{
Financial frictions and substitution between internal and external funds in publicly traded brazilian companies*
}

\author{
Márcio Telles Portal - Brazil \\ M.Sc. in Accountancy, Universidade do Vale do Rio dos Sinos, Brazi \\ Auxiliary Professor, Center of Economic Sciences, Universidade do Vale do Rio dos Sinos, Brazil \\ e-mail: mtportal@unisinos.br
}

João Zani - Brazil

Ph.D. in Business Administration, Universidade Federal do Rio Grande do Sul, Brazil

Adjunct Professor, Universidade do Vale do Rio dos Sinos, Brazil

e-mail: jzani@unisinos.br

Carlos Eduardo Schönerwald da Silva - Brazil

Ph.D. in Economics, University of Utah, USA

Adjunct Professor, Universidade Federal do Rio de Janeiro, Brazil

e-mail: cschonerwald@ufri.br

Received on 8.23.2011 - Accepted on 11.17.2011 - $3^{\text {rd }}$ version on 2.27.2012

\begin{abstract}
The present study aimed to document the effects of financial constraints on the negative relationship between cash flow and external funds, a phenomenon associated with the Pecking Order Theory. This theory suggests that companies subject to more expensive external funds (financially constrained firms) should demonstrate a stronger negative relationship with cash flow than companies subject to minor financial frictions (financially unconstrained firms). The results indicate that the external funds of constrained firms consistently present less negative sensitivity to cash flow compared with those of unconstrained companies. Additionally, the internal funds of constrained companies demonstrate a positive sensitivity to cash flow, whereas those of unconstrained companies do not show any such significant behavior. These results are in accordance with the findings of Almeida and Campello (2010), who suggest the following: first, because of the endogenous nature of investment decisions in constrained companies, the complementary relationship between internal and external funds prevails over the substitutive effects suggested by the Pecking Order Theory; and second, the negative relationship between cash flow and external funds cannot be interpreted as evidence of costly external funds and therefore does not corroborate the Pecking Order Theory.
\end{abstract}

Keywords: Financial constraint. Pecking order. Cash policy. Debt policy. Capital structure. 


\section{INTRODUCTION}

The literature on capital structure has treated investments as exogenous to financial policies (Fama and French, 2002; Shyam-Sunder and Myers, 1999). However, extensive studies on financial constraints (Fazzari, Hubbard and Petersen, 1988; Hubbard, 1998; Almeida, Campello and Weisbach, 2004) have presented evidence that because of financial frictions, not all companies can fully finance their investment opportunities. As a result, some companies experience financial constraints. In this state, investment decisions become endogenous to financial policies.

Few studies have attempted to reconcile these two views from the literature with regard to financing-investment interactions. Almeida and Campello (2010) attempt to do so in a study re-interpreting capital structure, which is a consolidated fact in the literature, in the light of the Pecking Order Theory. Specifically, the authors find that there is a negative relationship between the generation of internal funds and the demand for external financing. The authors present evidence that a reduction in the demand for external funds is less sensitive to the internal generation of funds in constrained companies (i.e., is subject to greater financial frictions). This finding contradicts the Pecking Order Theory and suggests that this behavior is associated with the complementarity between external and internal funds because of the effect of endogenous investment.

Prior evidence suggests that the individual characteristics of each company affect the company's ability to raise external funds and that environmental variables exert a moderating effect. Institutional characteristics shape the orientation of the financial system and companies because countries with weak protection for investors and lenders tend to have less developed capital markets, and companies, which are ownership structures that primarily serve as a substitute for legal protection (La Porta, Lopez-de-Silanes, Shleifer and Vishny, 1998, 1999), tend to raise transaction and capital costs and limit access to external financing sources by increasing incentives to maintain liquidity (Diittmar, Mahrt-Smith and Servaes, 2003; Kalcheva and Lins, 2007; Baum, Shäfer and Talavera, 2009; Khurana, Martin and Pereira, 2006).

The present study sought to question whether the behavior of Brazilian companies fits the arguments and the USA-derived evidence of Almeida and Campello (2010). In other words, the study aimed to evaluate empirically whether the relationship between the generation of internal funds and the demand for external funds is more negative for financially unconstrained firms than for constrained firms and whether such behavior is associated with the endogenous nature of investments under financial constraints. This study is relevant to Brazilian companies in several ways. First, the evidence suggests that environmental differences determine the behavior of companies while changing the funding structures and the degree of financial friction, which may involve a change in the substitutive/complementary relationship between external and internal funds. Second, Bekaert and Harvey's (2002) arguments about the need to develop research in emerging markets present theoretical and empirical challenges. Third, the environmental differences (La Porta et al., 1998) between Brazil and the United States are reflected in the companies' cash (Koshio and Cia, 2004) and debt policies (Leal, 2008).

The gap addressed in the present study shows the need to reconcile capital structure theories with the endogenous investment implications arising from financial constraints in emerging economies such as Brazil. The results obtained here indicate the need for a review of significant national data that support the research on capital structures.

The present study is structured as follows: section 2 presents the literature review; section 3 presents the methodological aspects; section 4 analyzes the results of empirical testing; and section 5 presents the final considerations.

\section{LITERATURE REVIEW}

Modigliani and Miller (1958) suggest that the value of a company is independent from the form in which it is financed. Therefore, the separation theorem is valid (i.e., in a friction-free environment, companies can fully finance their investment opportunities to create value without depending on financing decisions). Theoretical studies have questioned the validity of these propositions in the presence of market friction, such as asymmetric information (Myers and Majluf, 1984) and agency problems (Jensen and Meckling, 1976). These frictions can generate anything from an increase in the cost of external funds for internally generated funds to credit rationing (Stiglitz and Weiss, 1981). Under these conditions, companies are characterized as financially constrained in that they make suboptimal investment decisions because of their insufficient internal and external sources of financing. Thus, these companies underinvest and incur a reduction in value.

The study by Fazzari, Hubbard and Petersen (1988) is a milestone in the literature on the relations of the cost differential between internal and external sources of financing and their effects on companies' investment policies. These authors find evidence that the investment decisions of companies depend not only on the net present value (NPV) of projects but also on the variation in the availability of internal resources, accor- 
ding to the degree of financial constraint. The authors' largest empirical contribution is to examine the influence of financial frictions on corporate investment by empirically comparing investment-cash flow sensitivity among groups of companies subject to varying degrees of financial friction (and hence to varying degrees of financial constraint).

However, some authors, such as Erickson and Whited (2000), have questioned Fazzari, Hubbard and Petersen's (1988) empirical strategy, which focuses mainly on the potentially informative content of cash flow on investment opportunities. The study by Almeida, Campello and Weisbach (2004) responds to such criticism. Their work not only proposes a new empirical strategy but also enables the relationship between financial constraints, financial policies and investment to be extended in light of the companies' cash policies. This extension follows from the assumption that if companies face a costly financing source, they modify their current financial policies by increasing their cash volume to enable more valuable future investments. The trade-off from the costs and benefits of the inter-temporal adjustments of liquidity prioritization generates the empirical implication that constrained companies should demonstrate a systematic and positive sensitivity to cash flow. In contrast, unconstrained companies should not present this systematic behavior.

However, the literature on capital structure has neglected to address the effects of financial constraints on the interaction between financing and investment, despite the theoretical arguments and evidence regarding this subject (Fazzari, Hubbard and Petersen, 1988; Almeida, Campello and Weisbach, 2004; Baum, Shäfer and Tavalera, 2009; Khurana, Martin and Pereira, 2006; Faulkender and Wang, 2006). Almeida and Campello's (2010) study helps to address this gap, particularly with regard to the Pecking Order Theory.

The Pecking Order Theory suggests that in the face of high external financing costs, companies should prefer to finance their investments with internal funds because of information asymmetry. This preference causes the companies subject to costly external funds to present a negative ratio of the generation of internal funds (cash flow) to the demand for external funds (Myers, 1984; Myers and Majluf, 1984). Empirical studies in Brazil have documented this negative relationship and have suggested a behavioral element of the Pecking Order Theory (Bastos, Nakamura and Basso, 2009; Medeiros and Daher, 2008; Nakamura et al., 2007).

Thus, if the negative relationship between cash flow and the demand for external funds is due to the cost of external financing, companies subject to costly external funds must present a stronger negative relationship than companies not subject to financial frictions. However, Almeida and Campello (2010) present robust evidence suggesting that this negative relationship is stronger in those companies less likely to be under strong financial frictions (financially unconstrained firms). Thus, contrary to the viewpoint established in the literature, these findings cannot be interpreted as evidence for external financing costs arising from information asymmetry.

Almeida and Campello (2010) suggest that the endogenous effects of investment on external financing decisions may explain this behavior. The pecking order argument ignores the possibility that investment decisions become endogenous because internal funds are insufficient to finance them and the cost of external funds is prohibitively high. The endogeneity of investment presents three fundamental soothing effects of the substitutivity between external and internal funds in constrained companies.

First, constrained companies face sub-investments and subject the decision to use internal funds to a trade-off between the reduction in their exposure to external funds and the increase in their current investments. Given the high cost of investment opportunities, constrained companies would find it relatively more advantageous to direct more internal funds toward their current investments.

Second, constrained companies adjust their current financial policies to mitigate the adverse effects of financial constraints on both current and future investments. Constrained companies adjust to ensure that sufficient funds are available to meet their investment opportunities by targeting the generation of internal funds (cash flow) to increase the available volume of liquid assets (internal funds) as cash and short-term investments (Almeida, Campello and Weisbach, 2004) and working capital (Fazzari and Petersen, 1993) while directing less internal funds towards the reduction of external funds.

Third, constrained companies' internal funds and capacity to raise external funds are complementary because of the credit multiplier effect. As the company's cash flow and other internal funds are directed to collateralizable assets, new external funds are raised in turn. When applied in new collateralizable assets (i.e., physical and liquid assets that can be used as security), these new external funds establish a systematic behavior that amplifies the positive effect of internal funds on the capacity to raise external funds (Almeida and Campello, 2007) by reducing the costs of external funds (Bernanke and Gertler, 1989) and increasing their collateral value (Kiyotaki and Moore, 1997). 


\section{METHODOLOGICAL PROCEDURES}

To document how the relationship between external and internal funds is affected by financial constraints, we followed three steps: 1) define the empirical tests ${ }^{1}$ to be used; 2) define the classification criteria of the companies a priori according to their financial state (constrained or unconstrained); and 3) define the sample, the procedures for collecting and processing the data and the sampling restrictions.

\subsection{Empirical tests}

The first test aimed to verify whether the classification criteria selected to separate financially constrained and unconstrained companies were consistent. Following the approach suggested by Almeida, Campello and Weisbach (2004), we expected constrained companies to have a significant and positive sensitivity to cash flow and unconstrained companies to show no such significant behavior. The following model estimated by least squares in two stages (LS2S) was adopted, with fixed effects for company and year (Model 1):

$$
\begin{aligned}
\Delta R C_{i, t} & =\beta_{0}+\beta_{1} C F_{i, t}+\beta_{2} Q_{i, t}+\beta_{3} \operatorname{Ln}(T A)_{i, t}+\beta_{4} \Delta(C A-C)_{i, t} \\
& +\beta_{5} S T D_{i, t}+\beta_{6} P A A_{i, t}+e_{i, t^{\prime}}
\end{aligned}
$$

where $\Delta \mathrm{CR}$ was defined as the annual change in the sum of cash and short-term financial investments ${ }^{2}$. Cash flow (CF) is defined as net income plus depreciation and minus dividends and interest on the company's own capital. The size Ln (TA) was defined as the neperian logarithm of the book value of the company's assets for the period. Including the size allows us to control for the effects of transaction costs and economies that affect cash and debt policy decisions. As a proxy for investment opportunity, we used Tobin's Q, measured as total assets - equity + market value of shares / total assets.

The following additional variables were used as controls for substitutes and cash flow: $\triangle \mathrm{CA}-\mathrm{C}$, the sum of the change in current assets minus the change in cash reserves (CR); $\Delta \mathrm{STD}$, the variation in the short-term financial debt (bonds and financing); and applications in permanent assets (PAA), including affiliated companies and subsidiaries. All of the variables except Ln (TA) were divided by the total assets. To recognize a possible endogeneity of the variables, we used a two-year gap of endogenous variables as the instrument.

The second test aimed to verify whether investment endogeneity mitigates the substitutive relationship between external and internal funds, which would imply that external funds (debt and equity) are more sensitive to reduced cash flow for constrained companies than for unconstrained companies. The model used two alternative specifica- tions for the sensitivity of external funds to cash flow. The first specification, estimated by Ordinary Least Squares (OLS) with fixed effects for company and year (Model 2), only includes proxies for the variables that are believed to capture primary information related to the theory: cash flow, investment opportunities and size. This model was calculated as:

$$
\begin{aligned}
\Delta F E_{i, t} & =\alpha_{1} C F_{i, t}+\alpha_{2} Q_{i, t}+\alpha_{3} \operatorname{Ln}(T A)_{i, t}+\sum_{i} \text { company }_{i} \\
& +\sum_{t} \text { year }_{t}+e_{i, t^{\prime}}
\end{aligned}
$$

where $(\triangle \mathrm{EF})$ is defined as the change in external sources of financing and the proxy is measured as the sum of the net issuance of debt (annual change of the debentures and short-term and long-term financing) and net emission of shares (NES), measured as the annual change of stockholders' equity minus the retained profits. Cash flow is defined as the net income plus depreciation and amortization. These variables were divided by the total assets.

The second specification for the sensitivity of external financing considers the effects of pre-existing balances (one year lag) in the internal funds, the initial capital structure and the collateralizable assets on the debt policy. To control the pre-existing internal funds, we adopted the cash reserve (CR) and the sum of the client accounts and stocks, defined as other liquid assets (OLA). As tangible/collateralizable assets, we used the balance in fixed assets (FA) and measured the initial capital structure as the ratio of debt to equity (Debt/Eq). These variables were divided by the total assets, with the exception of Debt/Eq. The model was estimated by the Generalized Method of Moments (GMM) in two steps, with fixed effects for company and year. The model was specified as follows:

$$
\begin{aligned}
\Delta F E_{i, t} & =\alpha_{1} C F_{i, t}+\alpha_{2} Q_{i, t}+\alpha_{3} \operatorname{Ln}(T A)_{i, t}+\alpha_{4} C R_{i, t-1}+\alpha_{5} O L A_{i, t-1} \\
& +\alpha_{6} F A_{i, t-1}+\alpha_{7} \text { Debt } / E Q_{t-1}+\sum_{i} \text { company }+\sum_{\mathrm{t}} \text { year }+\varepsilon_{i, t,}
\end{aligned}
$$

where FA and Debt/Eq were considered to be endogenous variables. Two lags of the endogenous variables were used as instruments ${ }^{3}$.

The third test was intended to show that the internal and external funds in constrained companies exhibited greater complementarity than the funds of unconstrained companies. Empirically, we hoped that compared with the unconstrained companies' funds, the constrained companies' external funds and internal funds would demonstrate less negative sensitivity and greater positive sensitivity to cash flow, respectively. The behavior was noted by contrasting the sensitivity of the constrained and unconstrained companies' in-

${ }^{1}$ Auxiliary tests: diagnosis of multicollinearity using the correlation matrix of the variables for each group and variance inflation factor (VIF); heteroscedasticity diagnostics using modified Wald statistics for fixed effects-OLS and Pagan-Hall for fixed effects-IV; and use of the Baltagi-Wu autocorrelation test and Bhargava, Franzini and Narendranathan's test, which is appropriate for fixed effects. The estimates are robust to section 4 heteroscedasticity and autocorrelation using the Eiker-Huber-White variance estimator. 
ternal and external funds to their cash flows. We used the Seemingly Unrelated Regressions (SUR) with fixed effects for company and year to capture this concurrent behavior between the policies from the same company (Models 4 and 5):

$$
\begin{aligned}
\Delta F E_{i, t} & =\alpha_{1} F C_{i, t}+\alpha_{2} Q_{i, t}+\alpha_{3} \text { Size }_{i, t}+\sum_{t} \text { company }_{i} \\
& +\sum_{t} \text { year }+e_{i, t}^{F E} \\
\Delta F I_{i, t} & =\beta_{1} F C_{i, t}+\beta_{2} Q_{i, t}+\beta_{3} \text { Size }_{i, t}+\sum_{i} \text { company }_{i} \\
& +\sum_{t} \text { year }_{t}+e_{i, t}^{F I}
\end{aligned}
$$

where $\Delta \mathrm{IF}$ captures the variation in internal funds. In this study, the proxy was measured as the variance of the sum of the CR and OLA. These variables were divided by the total assets.

We ran Models 3 and 4 to verify the sensitivity of the external funds and to detect the isolated debt sensitivity. The objective was to identify the possible differences in behavior due to the source of external funds and to avoid potential problems with measuring the proxy for net share issuance.

\subsection{Classification method a priori regarding the financial state}

Considering the criteria used in previous studies and the local characteristics and limitations of publicly available data, we proposed the following criteria for classifying the companies' financial constraints: total payout (PAY); American Depositary Receipt (ADR) issuance; and the intersection between the Size and Total Payout criteria (SIZEกPAY). For the 1995-2005 period, the companies were ranked annually according to these criteria.

\subsubsection{Classification based on Total Payout (PAY)}

PAY is defined as the sum of dividends and interest on the company's own capital divided by its net profit. The companies that did not pay annual dividends ${ }^{4}$ or interest on capital and that did not make any repurchases were classified as financially restricted. Among the companies that submitted a PAY greater than zero, the companies of the lower three deciles of the distribution were considered financially constrained companies, whereas the companies of the top three deciles were classified as financially unconstrained.

This classification is justified by Fazzari, Hubbard and Petersen's (1988) argument because the conditioning from the payment of dividends is supported by the effects of asymmetric information on the differential of the costs and limits of internal and external funds. According to Myers and Majluf (1984), this differential justifies the existence of financial clearance and the preference for internally generated funds, which creates a hierarchy of financing sources. In this situation, not paying or reducing dividends would benefit shareholders because these resources can be applied in investment opportunities with positive NPV, which otherwise could not be financed because of the depletion of other internal funds.

Other evidence from prior studies strengthens this argument. Fama and French (2002) suggest that the lowest dividend payment can be associated with difficulties in accessing external sources of financing. In Brazil, a negative relationship has been found between growth opportunities and payout (Futema, Basso and Kayo, 2009; Iquiapaza, Amaral and Lamounier, 2008).

\subsubsection{ADR issuers (ADR)}

The companies were classified annually based on the condition that they are broadcasting American Depositary Receipts (ADR) of levels 2 and 3. The companies issuing ADRs were considered financially unconstrained, whereas those that did not present ADRs annually were considered financially constrained. Unlike Brazilian studies, studies in the USA do not adopt this criterion. However, according to Bruni (2002), this criterion can be used to identify companies that are subject to major informational requirements by the Securities and Exchange Commission (SEC) and subject to the lower costs of capital and limitations to local offers of external funds. In Brazil, Costa, Paz and Funchal (2008) find evidence consistent with the findings of Almeida, Campello and Weisbach (2004) by using the ADR issuance as a classification criterion.

\subsubsection{Intersection between the criteria of Size and Total Payout (SIZE $\cap$ PAY)}

We used the intersection between the observations of the companies classified according to the criteria of Size and Total Payout. In other words, only the companies that presented the same state in both criteria were classified as constrained or unconstrained. The goal of this classification scheme was to promote more restrictive conditions among classifications because the Brazilian studies (e.g., Costa and Paz, 2004) that applied the two criteria separately have failed to achieve the theoretical results.

Using the criterion Size, we classified the companies for each year by using the total asset proxy. The companies in the three lower deciles of the distribution of total asset size were considered financially constrained, and those in the three higher deciles were considered financially unconstrained.

The use of the Size criterion is justified by the evidence showing that the size of the company is associated with the degree of friction to which it is exposed (Fama and French, 2002; Frank and Goyal, 2003). Faulkender's (2002) findings suggest that smaller companies are subject to greater informational asymmetry and high transaction costs. Additionally, these companies do not be-

\footnotetext{
${ }^{4}$ The law 6404/76 and the more recent law 10303/01 predict that if the status is omitted and the General Assembly considers changing it to introduce a standard on the dividend policy, the mandatory dividend may not be less than $25 \%$ of the adjusted net income. Therefore, the companies with zero payouts may be separated because, otherwise, some companies with this characteristic or with less than 0.25 payouts could be classified as unconstrained. No company classified as unrestricted presented a total payout of less than $25 \%$. Additionally, the descriptive statistics reported in Table 1 indicate that the criteria adopted are capable of discriminating between the companies in those two states.
} 
nefit from financial economies of scale (i.e., they have greater difficulties in accessing external sources of financing). According to Fama and French (2002), because size is positively correlated with age, smaller companies are less likely to have developed histories that allow investors to distinguish between companies with good and poor abilities to pay.

\subsection{Sample}

The population of the present study includes all non-financial publicly traded Brazilian companies whose accounting and market information were available in the Economática database for the 1995-2005 period. We adjusted the data to 2005 values by using the General Price Index-Internal Availability (GPI-IA).
We eliminated the observations that presented at least one of the following restrictions: (a) did not provide indebtedness in any year in the period under review; (b) had surplus cash reserves below $\mathrm{R} \$ 500,000$; (c) had annual growth in net sales or total assets that exceeded $100 \%$; (d) exhibited a $Q$ value less than 0 or greater than 10; and (e) had debts greater than the book value of the assets.

These sample restrictions have the following purposes: (a) and (b) serve to exclude the companies that were unable to adopt active cash and debt policies; (c) eliminates the companies that experienced significant changes in the fundamentals of their businesses; (d) mitigates the potential effects of measurement errors related to the variable Q; and (e) eliminates the companies that could have been close to default.

\section{ANALYSES OF THE RESULTS}

The sample consisted of 1,836 observations and 326 companies. Table 1 provides the descriptive statistics as well as the mean (M) and standard deviation (SD) of the variables used in the estimates for the full sample and for the groups of constrained (C) and unconstrained $(\mathrm{U})$ companies for each of the three sorting criteria. It also presents the $\mathrm{p}$-value $(\mathrm{PV})$ of the $\mathrm{t}$ test for the mean differences $(\mathrm{C} \neq \mathrm{U})$ of the variables between the groups.

In general, the independent variables mainly presented mean differences that were statistically significant at a $10 \%$ level, which indicates that the classification criteria presented discriminating behavior for the variables tested. In short, the constrained companies revealed lower cash flows, lower investment opportunities, lower Ln (TA), lower cash reserves, less application in permanent assets, less debt and fewer fixed assets while presenting a greater balance in other liquid assets, a greater balance in internal funds and a higher debt/Eq ratio than the unconstrained companies. These descriptive statistics suggest that the theoretical profiles of the constrained and unconstrained companies most strongly identified by the debt, internal funds and cash flow variables are empirically valid.

This section describes the results of the empirical tests. Table 2 presents the results of the first test, which aimed to verify whether the groups' behavior matched the empirical implications of Almeida, Campello and Weisbach's (2004) theory (i.e., constrained companies have a positive and statistically significant sensitivity to cash flow, whereas unconstrained companies demonstrate indifferent behavior).

Table 1 Descriptive statistics of the sample and groups

\begin{tabular}{|c|c|c|c|c|c|c|c|c|c|c|}
\hline \multirow{3}{*}{ Variables } & \multirow{2}{*}{$\begin{array}{c}\text { Complete } \\
\text { Sample }\end{array}$} & \multicolumn{3}{|c|}{ ADR } & \multicolumn{3}{|c|}{ PAY } & \multicolumn{3}{|c|}{ SIZE $\cap P A Y$} \\
\hline & & C & U & $\mathrm{C} \neq \mathrm{U}$ & C & U & $\mathrm{C} \neq \mathrm{U}$ & C & U & $\mathrm{C} \neq \mathrm{U}$ \\
\hline & $\mathrm{M} /(\mathrm{SD})$ & $\mathrm{M} /(\mathrm{SD})$ & $\mathrm{M} /(\mathrm{SD})$ & PV & $\mathrm{M} /(\mathrm{SD})$ & $\mathrm{M} /(\mathrm{SD})$ & PV & $\mathbf{M} /(\mathrm{SD})$ & $\mathrm{M} /(\mathrm{SD})$ & PV \\
\hline \multirow{2}{*}{$\Delta \mathrm{EF}$} & 0,0321 & 0,0307 & 0,0453 & \multirow{2}{*}{0,200} & 0,0344 & 0,0277 & \multirow{2}{*}{0,454} & 0,0273 & 0,0324 & \multirow{2}{*}{0,679} \\
\hline & $(0,144)$ & $(0,145)$ & $(0,137)$ & & $(0,160)$ & $(0,127)$ & & $(0,155)$ & $(0,133)$ & \\
\hline \multirow{2}{*}{$\Delta$ Debt } & 0,0022 & 0,0007 & 0,0158 & \multirow{2}{*}{0,090} & $-0,0055$ & 0,0095 & \multirow{2}{*}{0,031} & $-0,0150$ & 0,0138 & \multirow{2}{*}{0,002} \\
\hline & $(0,114)$ & $(0,114)$ & $(0,112)$ & & $(0,127)$ & $(0,098)$ & & $(0,121)$ & $(0,086)$ & \\
\hline \multirow{2}{*}{ NES } & 0,0302 & 0,0302 & 0,0300 & \multirow{2}{*}{0,976} & 0,0401 & 0,0189 & \multirow{2}{*}{0,000} & 0,0424 & 0,0210 & \multirow{2}{*}{0,037} \\
\hline & $(0,100)$ & $(0,101)$ & $(0,092)$ & & $(0,118)$ & $(0,078)$ & & $(0,136)$ & $(0,074)$ & \\
\hline \multirow{2}{*}{ CF } & 0,0612 & 0,0562 & 0,1063 & \multirow{2}{*}{0,000} & 0,0247 & 0,0946 & \multirow{2}{*}{0,000} & $-0,0016$ & 0,0923 & \multirow{2}{*}{0,000} \\
\hline & $(0,096)$ & $(0,098)$ & $(0,071)$ & & $(0,108)$ & $(0,063)$ & & $(0,129)$ & $(0,063)$ & \\
\hline \multirow{2}{*}{ Q } & 0,9695 & 0,9322 & 1,3005 & \multirow{2}{*}{0,000} & 0,9389 & 0,9724 & \multirow{2}{*}{0,435} & 0,8650 & 1,0030 & \multirow{2}{*}{0,040} \\
\hline & $(0,722)$ & 0,708 & $(0,757)$ & & $(0,825)$ & $(0,496)$ & & $(0,906)$ & $(0,487)$ & \\
\hline \multirow{2}{*}{$\operatorname{Ln}(T A)$} & 6,1810 & 6,0844 & 7,0534 & \multirow{2}{*}{0,000} & 6,0057 & 6,4698 & \multirow{2}{*}{0,000} & 5,2792 & 7,0112 & \multirow{2}{*}{0,000} \\
\hline & $(0,745)$ & $(0,704)$ & $(0,498)$ & & $(0,733)$ & $(0,678)$ & & $(0,488)$ & $(0,387)$ & \\
\hline \multirow{2}{*}{ CR } & 0,0891 & 0,0860 & 0,1172 & \multirow{2}{*}{0,000} & 0,0720 & 0,0907 & \multirow{2}{*}{0,001} & 0,0517 & 0,0716 & \multirow{2}{*}{0,006} \\
\hline & $(0,109)$ & $(01,109)$ & $(0,108)$ & & $(0,103)$ & $(0,105)$ & & $(0,085)$ & $(0,082)$ & \\
\hline \multirow{2}{*}{ CAC } & 0,2506 & 0,2615 & 0,1508 & 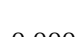 & 0,2502 & 0,2194 & & 0,3176 & 0,1398 & \\
\hline & $(0,168)$ & $(0,171)$ & $(0,086)$ & 0,000 & $(0,171)$ & $(0,149)$ & 0,001 & $(0,194)$ & $(0,095)$ & 0,001 \\
\hline
\end{tabular}




\begin{tabular}{|c|c|c|c|c|c|c|c|c|c|c|}
\hline \multirow{3}{*}{ Variables } & \multirow{2}{*}{$\begin{array}{c}\text { Complete } \\
\text { Sample }\end{array}$} & \multicolumn{3}{|c|}{ ADR } & \multicolumn{3}{|c|}{ PAY } & \multicolumn{3}{|c|}{ SIZE PAY } \\
\hline & & C & $\mathrm{u}$ & $\mathrm{C} \neq \mathrm{U}$ & C & $\mathrm{U}$ & $\mathrm{C} \neq \mathrm{U}$ & C & $\mathrm{U}$ & $\mathrm{C} \neq \mathrm{U}$ \\
\hline & $\mathrm{M} /(\mathrm{SD})$ & $\mathrm{M} /(\mathrm{SD})$ & $\mathrm{M} /(\mathrm{SD})$ & PV & $\mathrm{M} /(\mathrm{SD})$ & $\mathbf{M} /(\mathbf{S D})$ & PV & $\mathbf{M} /(\mathrm{SD})$ & $\mathbf{M} /(\mathbf{S D})$ & PV \\
\hline \multirow{2}{*}{ PAA } & 0,0768 & 0,0725 & 0,1136 & \multirow{2}{*}{0,000} & 0,0680 & 0,0873 & \multirow{2}{*}{0,000} & 0,0483 & 0,0974 & \multirow{2}{*}{0,000} \\
\hline & $(0,074)$ & $(0,072)$ & $(0,081)$ & & $(0,069)$ & $(0,078)$ & & $(0,053)$ & $(0,079)$ & \\
\hline \multirow{2}{*}{ Debt/Eq } & 1,1614 & 1,1865 & 0,9349 & \multirow{2}{*}{0,173} & 1,5614 & 0,8827 & \multirow{2}{*}{0,000} & 1,5317 & 1,0602 & \multirow{2}{*}{0,000} \\
\hline & $(2,412)$ & $(2,511)$ & $(1,169)$ & & $(3,148)$ & $(1,258)$ & & $(3,474)$ & $(1,150)$ & \\
\hline \multirow{2}{*}{$\Delta \mathrm{IF}$} & 0,0087 & 0,0074 & 0,0207 & \multirow{2}{*}{0,153} & 0,0035 & $-0,0017$ & \multirow{2}{*}{0,464} & $-0,0098$ & 0,0045 & \multirow{2}{*}{0,13} \\
\hline & $(0,114)$ & $(0,116)$ & $(0,092)$ & & $(0,126)$ & $(0,096)$ & & $(0,120)$ & $(0,065)$ & \\
\hline \multirow{2}{*}{ Debt } & 0,2482 & 0,2415 & 0,3084 & \multirow{2}{*}{0,000} & 0,2661 & 0,2419 & \multirow{2}{*}{0,014} & 0,2097 & 0,2873 & \multirow{2}{*}{0,013} \\
\hline & $(0,167)$ & $(0,168)$ & $(0,142)$ & & $(0,176)$ & $(0,155)$ & & $(0,171)$ & $(0,148)$ & \\
\hline \multirow{2}{*}{ Fixed Asset } & 0,4342 & 0,4265 & 0,5029 & \multirow{2}{*}{0,000} & 0,4346 & 0,4742 & \multirow{2}{*}{0,002} & 0,3746 & 0,5640 & \multirow{2}{*}{0,002} \\
\hline & $(0,219)$ & $(0,223)$ & $(0,167)$ & & $(0,226)$ & $(0,211)$ & & $(0,214)$ & $(0,200)$ & \\
\hline
\end{tabular}

Descriptive statistics: mean $(\mathrm{M})$ and standard deviation $(\mathrm{SD})$ of the variables used in the estimates for the full sample and for the groups of companies classified as financially constrained $(C)$ and unconstrained $(U)$ for each of the three classification criteria. The period is 1995-2005. Variation in external financing ( $\Delta E F)$ was measured as the sum of $\triangle \mathrm{DEBT}$ and NES. * DEBT was measured as the sum of short- and long-term financial indebtedness (debentures and financing). $\triangle \mathrm{DEBT}$ was measured as the short- and long-term variation in financial debt (debentures and financing). NES was measured as the changes in stockholders' equity minus retained profits. CF was measured as net income plus depreciation and amortization minus dividends and interest on equity capital. Q was measured as total assets - equity + market value of shares / total assets. Ln (TA) was measured as the logarithm of the assets' book value. CR was measured as the sum of cash and short-term financial investments. $\triangle \mathrm{CA}-\mathrm{C}$ was measured as the variation in current assets minus the variation in the cash reserve (CR). PAA was measured as the sum of permanent assets, including applications in affiliates and subsidiaries. DEBT/Eq was measured as the ratio of debt to equity. The variation in internal funds ( $\Delta \mathrm{IF}$ ) was measured as the sum of the variance in the cash reserve $(\mathrm{CR})$ and the change in customers and inventory. FA was measured as fixed assets. All of the variables were staggered by total assets, except for Q, $\mathrm{Ln}(\mathrm{TA})$ and DEBT/Eq. The $\mathrm{p}$-value (PV) represents the $t$ test for the mean differences $(\mathrm{C} \neq \mathrm{U})$ of the variables between the groups.

The estimates indicated a significant and positive sensitivity to cash flow for the constrained companies, whereas the unconstrained companies showed no such statistically significant behavior. These results occurred regardless of the classification criteria and corresponded to the behavior advocated by Almeida, Campello and Weisbach's (2004) theory. The estimates indicate that for each Real normalized by the total assets of cash flow, the constrained companies used between 20 and 60 cents of their available internal funds (in this case, cash reserves), whereas the unconstrained companies do not present any such significant behavior. The mean of the coefficients of the cash flow variable in Model 1 for the constrained companies was 0.4669, whereas in Almeida, Campello and Weisbach's (2004) study, the mean coefficient was found to be 0.2873 .

Table 2 Descriptive statistics of the sample and groups

\begin{tabular}{|c|c|c|c|c|c|c|c|c|c|c|}
\hline \multirow{2}{*}{$\begin{array}{l}\text { DV: } \Delta \mathrm{CR}_{\mathrm{i}, \mathrm{t}} \\
\text { Criteria }\end{array}$} & \multicolumn{7}{|c|}{ Independent Variables } & \multirow{2}{*}{ Sargan } & \multirow{2}{*}{$\mathrm{C}$} & \multirow{2}{*}{ WH } \\
\hline & Status & $\mathrm{CF}_{\mathrm{i}, \mathrm{t}}$ & $Q_{i, t}$ & $\operatorname{Ln}(\mathrm{TA})_{\mathrm{i}, \mathrm{t}}$ & $\Delta \mathrm{CA}-\mathrm{C}_{\mathrm{i}, \mathrm{t}}$ & $\Delta \mathrm{STS}_{\mathrm{i}, \mathrm{t}}$ & $\mathbf{P A A}_{\mathrm{i}, \mathrm{t}}$ & & & \\
\hline \multirow{4}{*}{$\mathrm{ADR}$} & \multirow{2}{*}{ Constrained } & 0.6022 & 0.0294 & -0.2878 & -0.4659 & 0.2088 & 0.0356 & \multirow{2}{*}{$(0.55)$} & \multirow{2}{*}{$(0.44)$} & \multirow{2}{*}{$(0.00)^{* * *}$} \\
\hline & & $(0.058)^{*}$ & $(0.090)^{*}$ & $(0.000)^{* * *}$ & $(0.000)^{* * *}$ & $(0.004)^{* * *}$ & 0.945 & & & \\
\hline & \multirow{2}{*}{ Unconstrained } & 0.7089 & -0.0435 & -0.0491 & -0.0511 & 0.0938 & 0.2263 & \multirow{2}{*}{$(0.55)$} & \multirow{2}{*}{$(0.45)$} & \multirow{2}{*}{$(0.00)^{* * *}$} \\
\hline & & $(0.241)$ & $(0.495)$ & $(0.761)$ & $(0.016)^{* *}$ & $(0.616)$ & $(0.436)$ & & & \\
\hline \multirow{4}{*}{ PAY } & \multirow{2}{*}{ Constrained } & 0.5959 & 0.0263 & -0.0731 & -0.3194 & -0.0159 & 0.0473 & \multirow{2}{*}{$(0.62)$} & \multirow{2}{*}{$(0.31)$} & \multirow{2}{*}{$(0.00)^{* * *}$} \\
\hline & & $(0.005)^{* * *}$ & $(0.007)^{* * *}$ & $(0.165)$ & $(0.001)^{* * *}$ & $(0.821)$ & (0.895) & & & \\
\hline & \multirow{2}{*}{ Unconstrained } & 0.9131 & 0.0090 & -0.1204 & -0.2824 & 0.4965 & -0.0530 & \multirow{2}{*}{$(0.31)$} & \multirow{2}{*}{$(0.66)$} & \multirow{2}{*}{$(0.00)^{* * *}$} \\
\hline & & \begin{tabular}{|l}
$(0.439)$ \\
\end{tabular} & $(0.730)$ & $(0.161)$ & $(0.023)^{* *}$ & $(0.001)^{* * *}$ & $(0.897)$ & & & \\
\hline \multirow{4}{*}{ SIZEกPAY } & \multirow{2}{*}{ Constrained } & 0.2026 & 0.0379 & 0.0039 & -0.1572 & 0.0408 & -0.194 & \multirow{2}{*}{$(0.58)$} & \multirow{2}{*}{$(0.18)$} & \multirow{2}{*}{$(0.00)^{* * *}$} \\
\hline & & \begin{tabular}{|l}
$(0.056)^{*}$ \\
\end{tabular} & $(0.067)^{*}$ & $(0.896)$ & $(0.035)^{* *}$ & $(0.511)$ & (0.598) & & & \\
\hline & \multirow{2}{*}{ Unconstrained } & 5.335 & -0.0897 & -0.338 & -0.716 & -0.2122 & 0.764 & \multirow{2}{*}{$(0.80)$} & \multirow{2}{*}{$(0.37)$} & \multirow{2}{*}{$(0.00)^{* * *}$} \\
\hline & & \begin{tabular}{|l|}
$(0.294)$ \\
\end{tabular} & $(0.441)$ & \begin{tabular}{|l|}
$(0.291)$ \\
\end{tabular} & $(0.217)$ & $\begin{array}{l}(0.735) \\
\end{array}$ & $(0.462)$ & & & \\
\hline
\end{tabular}

The results of the estimates by 2SLS (fixed effects for company and year) applying Model 1 to the groups of financially constrained (C) and unconstrained (U) companies for each of the three classification criteria. $\triangle \mathrm{CR}$ was measured as the change in the sum of cash and short-term investments. CF was measured as net income plus depreciation and amortization minus dividends and interest on equity capital. Q was measured as total assets - equity market value of shares / total assets. Ln (TA) was measured as the logarithm of the assets' book value. $\triangle \mathrm{CA}-\mathrm{C}$ was measured as the change in current assets minus the change in the cash reserve (CR). $\triangle$ STD was measured as the changes in short-term financial debt (debentures and financing). PAA was measured as the sum of permanent assets, including applications in affiliates and subsidiaries. All of the variables were staggered by total assets, except for $\mathrm{Q}$ and $\mathrm{Ln}$ (TA). The results ( $\mathrm{p}$-values) of the diagnostic statistics for over-identification constraints (Sargan test), exogeneity of instruments (difference in Sargan test, C) and endogeneity (Wu-Hausman test, WH) are also illustrated. The CF variables, Ln (TA), $\triangle$ STD, $\triangle$ CA-C and PAA, were considered endogenous in the model and were instrumentalized with the first and second lags. The sample comprises the annual observations for the 1995-2005 period. Robust estimates were performed using the Eiker-Huber-White estimator ${ }^{5}$. The p-values are presented in parentheses.

Note: ${ }^{* * *},{ }^{* *}$ and ${ }^{*}$ indicate statistical significance levels of 1,5 and $10 \%$, respectively.

Estimates were conducted via two-step GMM, which we proved to be robust to heteroscedasticity by using the xtivreg2, gmm2s command in the Stata/IC software 11.0, but the results proved to be qualitatively similar. 
In addition, Tobin's $\mathrm{Q}$ proved to be positive and significant only for the constrained companies. This finding was consistent with the empirical implications of the theory, according to which investment opportunities would be a concern only for constrained companies. As a result, these companies must adjust their financial policies (in this case, their cash policies) to avoid underinvestment.

Given the success with the measurement, the empirical verification and the theoretical correspondence of cash sensitivity to cash flow, we were able to start the second phase of the empirical tests.

The second test involved estimates intended to observe the pecking order behavior, as commonly reported in the literature, of negative and significant sensitivity between cash flow and debt. Equal estimates were performed to verify whether external funds (debt and equity) were negatively sensitive to cash flow. Panel A in Table 3 reveals a negative and statistically significant sensitivity (at 1\%) of external funds to cash flow for the complete sample. Thus, for each Real of internally generated funds (cash flow) normalized by assets, approximately 22 cents are used to reduce the demand for external funds. Panel B presents similar results. The results for the complete sample indicate a negative and significant sensitivity (at 5\%) of debt to cash flow. This finding indicates that for each Real of cash flow normalized by assets, approximately 9 cents are used to reduce the demand for debt.

When the companies are separated by their financial statuses, Table 3 demonstrates that the external funds (Panel A) and debt (Panel B) of both the constrained and unconstrained companies show a significant and negative sensitivity (at $10 \%$ ) to cash flow. However, the negative sensitivity of external funds is systematically higher for the unconstrained companies. For every Real normalized by the total assets of cash flow, the unconstrained companies use between 48 and 96 cents to reduce the demand for external funds, whereas the constrained companies use between 18 and 26 cents for this purpose. The same situation occurs with regard to the negative sensitivity of debt to cash flow; in this case, the unconstrained companies use between 42 and 61 cents to reduce the demand for debt, whereas the restricted companies use between 6 and 11 cents.

The mean of the coefficients of the cash flow variable in Model 2 for the sensitivity of external funds was -0.2171 for the constrained companies and -0.7023 for the unconstrained companies, whereas Almeida and Campello (2010) reported values of -0.0202 and -0.1505 , respectively.

Table 3

Sensitivity of External Funds/Debt to Cash Flow

\begin{tabular}{|c|c|c|c|c|c|c|c|}
\hline \multicolumn{8}{|c|}{ Panel A: Sensitivity Of External Funds to Cash Flow } \\
\hline \multicolumn{2}{|c|}{ DV: $\Delta$ External Funds } & \multicolumn{6}{|c|}{ Criteria } \\
\hline \multirow{2}{*}{$\begin{array}{l}\text { Independent } \\
\text { Variables }\end{array}$} & \multirow{2}{*}{$\begin{array}{l}\text { Complete } \\
\text { Sample }\end{array}$} & \multicolumn{2}{|c|}{ ADR } & \multicolumn{2}{|c|}{ PAY } & \multicolumn{2}{|c|}{ SIZEกPAY } \\
\hline & & Constrained & Unconstrained & Constrained & Unconstrained & Constrained & Unconstrained \\
\hline \multirow{2}{*}{$\mathrm{CF}_{\mathrm{i}, \mathrm{t}}$} & $-0,2200$ & $-0,2636$ & $-0,4862$ & $-0,2049$ & $-0,6521$ & $-0,1829$ & $-0,9687$ \\
\hline & $(0.006)^{* * *}$ & $(0.000)^{* * *}$ & $(0.027)^{* *}$ & $(0.005)^{* * *}$ & $(0.001)^{* * *}$ & $(0.055)^{*}$ & $(0.025)^{* *}$ \\
\hline \multirow{2}{*}{$\mathrm{Q}_{\mathrm{i}, \mathrm{t}}$} & 0,0068 & 0,0037 & 0,0512 & 0,0089 & 0,1036 & 0,0025 & 0,1060 \\
\hline & $(0.365)$ & $(0.684)$ & $(0.0560)^{*}$ & $(0.481)$ & $(0.007)^{* * *}$ & $(0.910)$ & $(0.051)^{*}$ \\
\hline \multirow{2}{*}{$\operatorname{Ln}(T A)_{i, t}$} & 0,1451 & 0,1509 & 0,2260 & 0,1061 & 0,2327 & $-0,0398$ & 0,3337 \\
\hline & $(0.050)^{* *}$ & $(0.000)^{* * *}$ & $(0.012)^{* *}$ & $(0.000)^{* * *}$ & $(0.003)^{* * *}$ & $(0.233)$ & $(0.006)^{* * *}$ \\
\hline $\mathrm{R}^{2}$ & 0,035 & 0,032 & 0,093 & 0,064 & 0,009 & 0,102 & 0,012 \\
\hline $\mathrm{N}$ & 1836 & 1644 & 182 & 951 & 415 & 354 & 211 \\
\hline \multicolumn{8}{|c|}{ Painel B: Sensitivity Of Debt To Cash Flow } \\
\hline \multicolumn{2}{|l|}{ DV: $\Delta$ Debt } & \multicolumn{6}{|c|}{ Criteria } \\
\hline \multirow{2}{*}{$\begin{array}{l}\text { Independent } \\
\text { Variables }\end{array}$} & \multirow{2}{*}{$\begin{array}{l}\text { Complete } \\
\text { Sample }\end{array}$} & \multicolumn{2}{|c|}{ ADR } & \multicolumn{2}{|c|}{ PAY } & \multicolumn{2}{|c|}{ SIZE PAY } \\
\hline & & Constrained & Unconstrained & Constrained & Unconstrained & Constrained & Unconstrained \\
\hline \multirow{2}{*}{$\mathrm{CF}_{\mathrm{i}, \mathrm{t}}$} & $-0,0965$ & $-0,0809$ & $-0,4262$ & $-0,0626$ & $-0,7192$ & $-0,1119$ & $-0,6077$ \\
\hline & $(0.020)^{* *}$ & $(0.065)^{*}$ & $(0.034)^{* *}$ & $(0.291)$ & $(0.000)^{* * *}$ & $(0.092)^{*}$ & $(0.015)^{* *}$ \\
\hline \multirow{2}{*}{$\mathrm{Q}_{\mathrm{i}, \mathrm{t}}$} & 0,0022 & $-0,0048$ & 0,0639 & 0,0000 & 0,0890 & $-0,0108$ & 0,0625 \\
\hline & $(0.745)$ & $(0.504)$ & $(0.018)^{* *}$ & $(0,978)$ & $(0.000)^{* * *}$ & $(0.481)$ & $(0.044)^{* *}$ \\
\hline \multirow{2}{*}{$\operatorname{Ln}(T A)_{i, t}$} & 0,0894 & 0,0229 & 0,0842 & $0.014^{* *}$ & $-0,0362$ & 0,0026 & $-0,0111$ \\
\hline & $(0.000)^{* * *}$ & $(0.087)^{*}$ & (0.478) & $(0,397)$ & $(0.455)$ & $(0.877)$ & $(0.875)$ \\
\hline $\mathrm{R}^{2}$ & 0,021 & 0,033 & 0,110 & 0,035 & 0,052 & 0,039 & 0,107 \\
\hline $\mathrm{N}$ & 1836 & 1632 & 182 & 937 & 420 & 342 & 211 \\
\hline
\end{tabular}

The results of the estimates by OLS (fixed effects for company and year) using Model 2 on the groups of financially constrained $\left(\mathrm{R}^{2}\right)$ and unconstrained $(\mathrm{N})$ companies for each of the three classification criteria. Panel A presents the results of the estimates using the variation in external funds (net issuance of shares plus net debt issuance) as a dependent variable (DV). Panel B presents the results of the estimates using the short- and long-term annual changes in financial indebtedness (financing and debentures) as the DV debt variation. $\Delta \mathrm{CR}$ was measured as the change in the sum of cash and short-term financial investments. CF was measured as net income plus depreciation and amortization minus dividends and interest on own capital. Q was measured as total assets - equity market value of shares / total assets. Ln (TA) was measured as the neperian logarithm of the assets' book value. The sample comprises the annual observations from 1995 to 2005 . Robust estimates were performed using the Eiker-Huber-White estimator. The p-values are reported in parentheses.

Note: ${ }^{* *},{ }^{* *}$ and ${ }^{*}$ indicate statistical significance levels of 1,5 and $10 \%$, respectively. 
The control variables for both Panel A and Panel B revealed low adherence to expectations. Investment opportunities presented a significant and positive relationship only for the unconstrained companies. The company size systematically revealed statistical significance only in Panel A, where it presented a positive relationship regardless of the classification criteria and the financial status.
Table 4 pertains to alternative specifications for the second test, where the model was estimated by GMM in two steps, including control variables for the sources of preexisting internal resources and lagged proxies for tangibility and capital structure. The estimates performed for the constrained and unconstrained companies in accordance with the three classification criteria reinforce the results described in Table 3.

Table 4 Sensitivity of External Funds to Cash Flow: Expanded Model

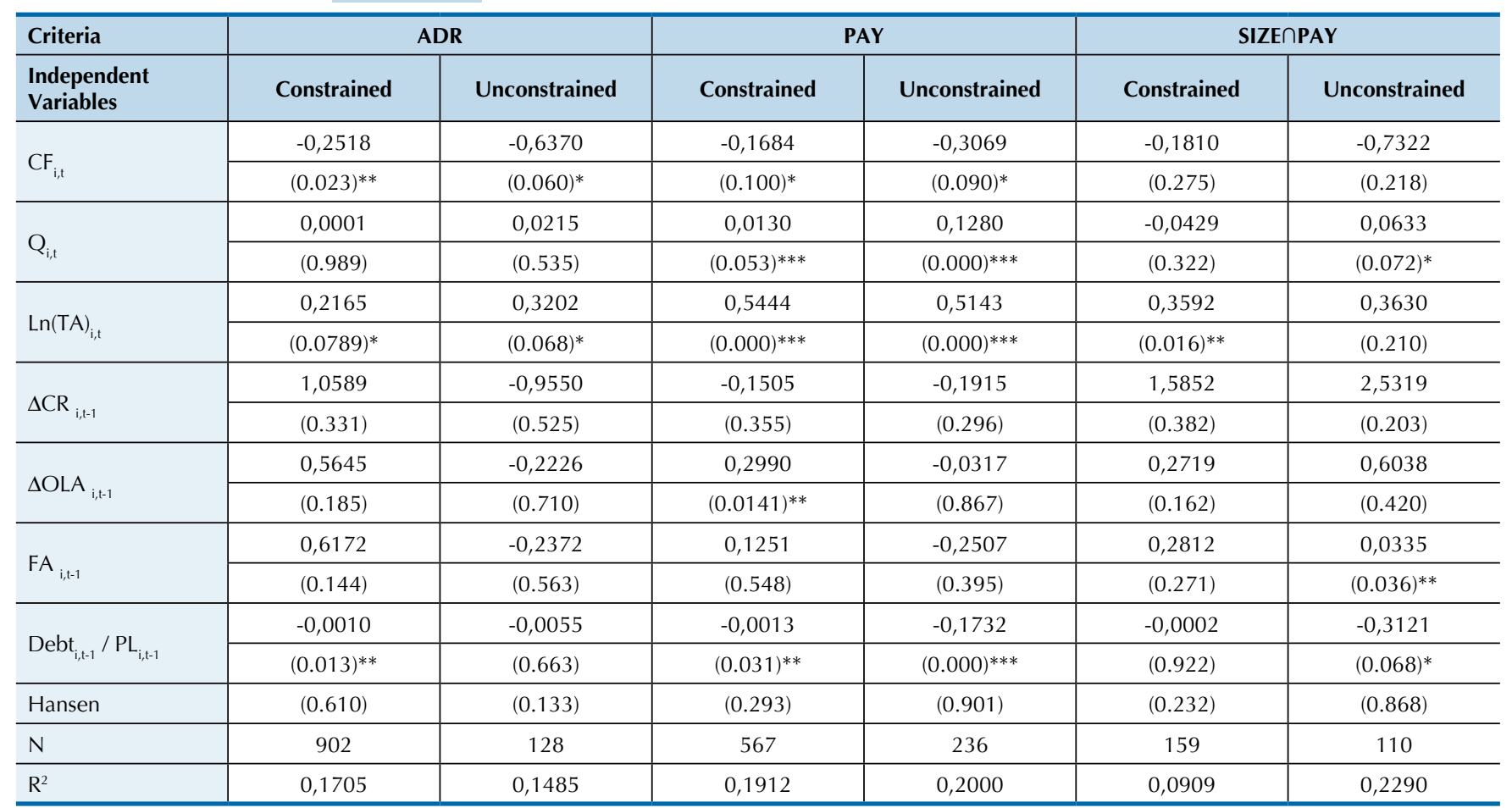

The results of the two-step GMM estimates (fixed effects for company and year) using Model 3 for the groups of financially constrained ( $\mathrm{R}^{2}$ ) and unconstrained $(\mathrm{N})$ companies for each of the three sorting criteria. The variation in External Financing $(\Delta \mathrm{EF})$ was measured as the sum of $\Delta \mathrm{DEBT}$ and $\mathrm{NES}$. CF was measured as net income plus depreciation and amortization minus dividends and interest on own capital. $\Delta C R$ was measured as the change in the sum of cash and short-term investments. Q was measured as total assets - equity + market value of shares / total assets. LN (TA) was measured as the logarithm of the assets' book value. $\triangle \mathrm{FA}$ was measured as the annual change in fixed assets. DEBT/Eq was measured as the ratio of DEBT to equity. All of the variables were staggered by total assets, except for Q, Ln (TA) and DEBT/Eq. The table also presents the p-value of Hansen's test statistic for the restrictions on identification. The sample comprises the annual observations from 1995 to 2005. Robust estimates were performed using the Eiker-Huber-White estimator. The $\mathrm{p}$-values are reported in parentheses.

Note: ${ }^{* *},{ }^{* *}$ and ${ }^{*}$ indicate statistical significance levels of 1,5 and $10 \%$, respectively.

Using the ADR and PAY classification criteria, we found that the external funds of the constrained companies presented a sensitivity to cash flow of between 16 and 25 normalized cents of assets, whereas those of the unconstrained companies presented a negative sensitivity to cash flow of between 30 and 63 cents. Using the SIZEกPAY criterion, we observed no statistically significant behavior, although the cash flow coefficient of the unconstrained companies was larger than that of the constrained companies. The Hansen test indicated that the employed instruments can be considered valid ${ }^{6}$. Additional control variables did not individualize systematic and significant behavior in the estimates, with the exception of the proxy for capital structure, which was negative in the estimates regardless of the companies' financial states.

The average of the coefficients of the cash flow variable in Model 3 for the sensitivity of capital was -0.2004 for the constrained companies and -0.5587 for the unconstrained companies, whereas Almeida and Campello (2010) reported values of -0.0194 and -0.1602 , respectively.

The results of the second test showed agreement with the results of past Brazilian empirical studies (Bastos, Nakamura and Basso, 2009; Medeiros and Daher, 2008; Nakamura et al., 2007), which associate the negative relationship between the generation of internal funds and the demand for external funds/debt with the Pecking Order Theory.

In general, the results of the second test suggest that the negative relationship between internal and external financing is more intense for the unconstrained companies that are less likely to be subject to higher financing costs. The constrained companies showed a smaller nega- 
tive relationship, which indicates that this relationship was mitigated. This behavior is systematic and incompatible with the explanation of the pecking order standard for the substitutivity between internal and external funds, which is based precisely on the cost of external financing. As discussed earlier, the investment endogeneity induced by the financial constraints most likely explains the greater complementarity between external and internal funds in the constrained companies.

Thus, in the third test, we sought to verify whether the complementarity between internal and external funds was greater for the constrained companies than for the unconstrained companies. The empirical implication is associated with the argument that investment decisions and financing are determined simultaneously. Additionally, it is associated with the credit multiplier effect that occurs if constrained companies manage their internal funds to increase their abilities to raise external funds. We expected the constrained companies' external and internal funds to present a minor negative sensitivity and a higher positive sensitivity to cash flow, respectively, in comparison with the unrestricted companies.

Table 5 presents the results estimated by seemingly unrelated regression (SUR) equations with fixed effects for company and year. These estimations used Models 4 and 5 on the groups of financially constrained and unconstrained companies for each of the three classification criteria. The SUR estimation allowed us to capture simultaneous behavior arising from each company's policies. The observed effect contrasts the sensitivity of the constrained and unconstrained companies' internal and external funds to their cash flows.

Panel A of Table 5 shows that the internal funds of constrained companies systematically present a positive sensitivity to cash flow. At the same time, the panel highlights the negative sensitivity of external funds to cash flow. Panel $\mathrm{B}$ shows that the internal funds of the unconstrained companies do not show a significant and systematic sen- sitivity to cash flow. Rather, their external funds exhibit a systematic, significant negative sensitivity to cash flow. Panel $\mathrm{C}$ indicates that the internal funds of the constrained companies systematically present a positive sensitivity to cash flow. However, their debt presents a non-significant negative sensitivity to cash flow. Panel D shows that the internal funds of the unconstrained companies do not reveal a significant, systematic sensitivity to cash flow. However, their debt demonstrates a systematic, significant negative sensitivity to cash flow.

The sensitivity of external funds to cash flow was systematically more negative for the financially unconstrained companies than for the financially constrained companies. In general, the results for the third test, which are reported in Table 5, support Almeida and Campello's (2010) hypothesis that the complementarity between internal funds and external funds is greater for constrained companies than for unconstrained companies because of the endogeneity of investment decisions, which contradicts the substitutivity between internal and external funds implied by the Pecking Order Theory.

We found that the mean of the coefficients of the cash flow variable for the sensitivity of internal funds in Model 4 was 0.3268 for the constrained companies, whereas Almeida and Campello (2010) reported a value of 0.0547. Similarly, we found that the average of the coefficients of the cash flow variable in Model 5 for the sensitivity of external funds was -0.0422 for the constrained companies and -0.2610 for the unconstrained companies. In comparison, Almeida and Campello (2010) reported values of -0.0128 and -0.1545 , respectively.

By comparing the mean of the coefficients of the present study for both constrained and unconstrained companies with the findings of Almeida and Campello (2010), we can observe that the positive sensitivity of internal funds to cash flow is systematically greater in the sample of Brazilian constrained companies than in the sample of American constrained companies.

Table 5 Financial Constraints and the Sensitivity of Internal/External Funds (Debt) to Cash Flow

\begin{tabular}{|c|c|c|c|c|c|c|c|c|c|}
\hline \multirow{4}{*}{ Criteria } & \multirow{4}{*}{ Dependent Variable } & \multicolumn{8}{|c|}{ Constrained } \\
\hline & & \multicolumn{6}{|c|}{ Variáveis Independentes } & \multirow[t]{2}{*}{$\mathbf{R}^{2}$} & \multirow[t]{2}{*}{$\mathbf{N}$} \\
\hline & & \multicolumn{2}{|c|}{$\mathrm{CF}_{\mathrm{i}, \mathrm{t}}(\boldsymbol{P}$-value $)$} & \multicolumn{2}{|c|}{$\mathrm{Q}_{\mathrm{i}, \mathrm{t}}(\boldsymbol{P}$-value $)$} & \multicolumn{2}{|c|}{$\operatorname{Ln}(\mathrm{TA})_{\mathrm{i}, \mathrm{e}}\left(\boldsymbol{P}_{\text {-value }}\right)$} & & \\
\hline & & \multicolumn{8}{|c|}{ Panel A } \\
\hline \multirow{2}{*}{ ADR } & $\Delta$ Internal Funds & 0,2998 & $(0,00)^{* * *}$ & 0,0129 & $(0,00)^{* * *}$ & 0,0051 & $(0,30)$ & 0,183 & \multirow{2}{*}{1515} \\
\hline & $\Delta$ External Funds & $-0,1506$ & $(0,00)^{* * *}$ & 0,0164 & $(0,00)^{* * *}$ & 0,0111 & $(0,04)^{* *}$ & 0,200 & \\
\hline \multirow{2}{*}{ PAY } & $\Delta$ Internal Funds & 0,3473 & $(0,00)^{* * *}$ & 0,0217 & $(0,00)^{* * *}$ & 0,006 & $(0,37)^{* * *}$ & 0,223 & \multirow{2}{*}{870} \\
\hline & $\Delta$ External Funds & $-0,1852$ & $(0,00)^{* * *}$ & 0,033 & $(0,00)^{* * *}$ & 0,0174 & $(0,03)^{* *}$ & 0,228 & \\
\hline \multirow{2}{*}{ SIZENPAY } & $\Delta$ Internal Funds & 0,3296 & $(0,00)^{* * *}$ & $-0,0079$ & $(0,48)$ & 0,0168 & $(0,25)$ & 0,345 & \multirow{2}{*}{327} \\
\hline & $\Delta$ External Funds & $-0,1165$ & $(0,04) * *$ & 0,0248 & $(0,08) *$ & 0,0218 & $(0,24)$ & 0,287 & \\
\hline
\end{tabular}




\begin{tabular}{|c|c|c|c|c|c|c|c|c|c|}
\hline \multirow{4}{*}{ Criteria } & \multirow{4}{*}{ Dependent Variables } & \multicolumn{8}{|c|}{ Constrained } \\
\hline & & \multicolumn{6}{|c|}{ Variáveis Independentes } & \multirow[t]{2}{*}{$\mathbf{R}^{2}$} & \multirow[t]{2}{*}{$\mathbf{N}$} \\
\hline & & \multicolumn{2}{|c|}{$\mathrm{CF}_{\mathrm{i}, \mathrm{f}}$ (P-value) } & \multicolumn{2}{|c|}{$\mathbf{Q}_{\mathrm{i}, \mathrm{t}}$ (P-value) } & \multicolumn{2}{|c|}{$\operatorname{Ln}(\mathrm{TA})_{\mathrm{i}, \mathrm{t}}(\boldsymbol{P}$-value $)$} & & \\
\hline & & \multicolumn{8}{|c|}{ Panel C } \\
\hline \multirow{2}{*}{ ADR } & $\Delta$ Internal Funds & 0,3041 & $(0,00)^{* * *}$ & 0,0137 & $(0,00)^{* * *}$ & 0,0060 & $(0,24)$ & 0,186 & \multirow{2}{*}{1458} \\
\hline & $\Delta$ Debt & $-0,0504$ & $(0,10)$ & $-0,0071$ & $(0,15)$ & 0,0177 & $(0,00)^{* * *}$ & 0,118 & \\
\hline \multirow{2}{*}{ PAY } & $\Delta$ Internal Funds & 0,3472 & $(0,00)^{* * *}$ & 0,0218 & $(0,00)^{* * *}$ & 0,0061 & $(0,37)$ & 0,230 & \multirow{2}{*}{873} \\
\hline & $\Delta$ Debt & $-0,0575$ & $(0,14)$ & $-0,0100$ & $(0,14)$ & 0,0190 & $(0,00)^{* * *}$ & 0,126 & \\
\hline \multirow{2}{*}{ 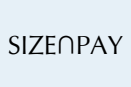 } & $\Delta$ Internal Funds & 0,3292 & $(0,00)^{* * *}$ & $-0,0079$ & $(0,48)$ & 0,0170 & $(0,24)$ & 0,345 & \multirow{2}{*}{328} \\
\hline & $\Delta$ Debt & $-0,0188$ & $(0,69)$ & $-0,0161$ & $(0,18)$ & $-0,0091$ & $(0,56)$ & 0,235 & \\
\hline
\end{tabular}

\begin{tabular}{|c|c|c|c|c|c|c|c|c|c|}
\hline \multirow{4}{*}{ Criteria } & \multirow{4}{*}{ Dependent Variables } & \multicolumn{8}{|c|}{ Unconstrained } \\
\hline & & \multicolumn{6}{|c|}{ Variáveis Independentes } & \multirow[t]{2}{*}{$\mathbf{R}^{2}$} & \multirow[t]{2}{*}{$\mathbf{N}$} \\
\hline & & \multicolumn{2}{|c|}{$\mathrm{CF}_{\mathrm{i}, \mathrm{t}}(\boldsymbol{P}$-value $)$} & \multicolumn{2}{|c|}{$\mathrm{Q}_{\mathrm{i}, \mathrm{t}}(\boldsymbol{P}$-value $)$} & \multicolumn{2}{|c|}{$\operatorname{Ln}(\mathrm{TA})_{\mathrm{i}, \mathrm{t}}(P$-value $)$} & & \\
\hline & & \multicolumn{8}{|c|}{ Panel B } \\
\hline \multirow{2}{*}{ ADR } & $\Delta$ Internal Funds & 0,027 & $(0,85)$ & 0,0298 & $(0,10)^{*}$ & $-0,0459$ & $(0,47)$ & 0,282 & \multirow{2}{*}{166} \\
\hline & $\Delta$ External Funds & $-0,4688$ & $(0,01)^{* *}$ & 0,0474 & $(0,04)^{* *}$ & 0,2262 & $(0,00)^{* * *}$ & 0,439 & \\
\hline \multirow{2}{*}{ PAY } & $\Delta$ Internal Funds & $-0,0271$ & $(0,77)$ & 0,0188 & $(0,11)$ & 0,0111 & $(0,16)$ & 0,218 & \multirow{2}{*}{382} \\
\hline & $\Delta$ External Funds & $-0,1976$ & $(0,05)^{*}$ & 0,0539 & $(0,00)^{* * *}$ & 0,0101 & $(0,25)$ & 0,392 & \\
\hline \multirow{2}{*}{ SIZEกPAY } & $\Delta$ Internal Funds & $-0,2084$ & $(0,03)^{* *}$ & 0,0172 & $(0,21)$ & 0,0238 & $(0,11)$ & 0,207 & \multirow{2}{*}{190} \\
\hline & $\Delta$ External Funds & $-0,187$ & $(0,23)$ & 0,0741 & $(0,00)^{* * *}$ & 0,0328 & $(0,16)$ & 0,384 & \\
\hline
\end{tabular}

\begin{tabular}{|c|c|c|c|c|c|c|c|c|c|}
\hline \multirow{4}{*}{ Criteria } & \multirow{4}{*}{ Dependent Variables } & \multicolumn{8}{|c|}{ Unconstrained } \\
\hline & & \multicolumn{6}{|c|}{ Variáveis Independentes } & \multirow[t]{2}{*}{$\mathbf{R}^{2}$} & \multirow[t]{2}{*}{$\mathbf{N}$} \\
\hline & & \multicolumn{2}{|c|}{$\mathrm{CF}_{\mathrm{i}, \mathrm{t}}(\mathrm{P}$-value $)$} & \multicolumn{2}{|c|}{$\mathbf{Q}_{\mathrm{i}, \mathrm{t}}(\boldsymbol{P}$-value $)$} & \multicolumn{2}{|c|}{$\operatorname{Ln}(\mathrm{TA})_{\mathrm{i}, \mathrm{t}}(P$-value $)$} & & \\
\hline & & \multicolumn{8}{|c|}{ Panel D } \\
\hline \multirow{2}{*}{ ADR } & $\Delta$ Internal Funds & $-0,0405$ & $(0,78)$ & 0,0285 & $(0,11)$ & $-0,0417$ & $(0,51)$ & 0,298 & \multirow{2}{*}{166} \\
\hline & $\Delta$ Debt & $-0,2705$ & $(0,14)$ & 0,0651 & $(0,00)^{* * *}$ & 0,1554 & $(0,05)^{* *}$ & 0,278 & \\
\hline PAY & $\Delta$ Debt & $-0,2988$ & $(0,00)^{* * *}$ & 0,0411 & $(0,00)^{* * *}$ & 0,0050 & $(0,50)$ & 0,356 & 389 \\
\hline \multirow{2}{*}{ SIZE $\cap P A Y$} & $\Delta$ Internal Funds & $-0,2084$ & $(0,03)^{* *}$ & 0,0172 & $(0,21)$ & 0,0238 & $(0,10)$ & 0,217 & \multirow{2}{*}{191} \\
\hline & $\Delta$ Debt & $-0,2136$ & $(0,08)^{*}$ & 0,0480 & $(0,00)^{* * *}$ & 0,0200 & $(0,27)$ & 0,340 & \\
\hline
\end{tabular}

The results of the SUR estimates (fixed effects for company and year) using Models 4 and 5 in the groups of financially constrained (Panels A and C) and unconstrained companies (Panels B and D) for each of the three classification criteria. Panels A and B present the results of the estimates for the sensitivity of external funds to cash flow, whereas panels $\mathrm{C}$ and $\mathrm{D}$ present the results of the estimates for the sensitivity of debt to cash flow. $\Delta \mathrm{DEBT}$ was measured as the short- and long-term changes in financial debt (debentures and financing). The variation in internal funds ( $\Delta \mathrm{IF}$ ) was measured as the sum of the annual variation in the cash reserve $(\Delta C R)$ and the variation in the other net assets ( $\triangle \mathrm{OLA})$. Cash flow (CF) was measured as net income plus depreciation and amortization minus dividends and interest on own capital. Investment opportunities (Q) were measured as total assets - equity + market value of shares / total assets. Size (Ln (TA)) was measured as the logarithm of the assets' book value. All of the variables were staggered by total assets, except for Q and Ln (TA). The sample comprises the annual observations from 1995 to 2005. Robust estimates were performed using the Eiker-Huber-White estimator. The p-values are reported in parentheses.

Note: ${ }^{* * *},{ }^{* *}$ and ${ }^{*}$ indicate statistical significance levels of 1,5 and $10 \%$, respectively.

Similarly, we noted that the external funds and debt of the constrained and unconstrained Brazilian companies systematically present greater negative sensitivity to cash flow than those of their US peers. This finding reinforces Khurana, Martin and Pereira's (2006) and Baum, Schäfer and Talavera's (2009) hypotheses that the internal funds of companies subject to less developed financial environments are prone to displaying greater positive sensitivity to cash flow because of the degree of financial development and the characteristics of the financial architecture (in terms of the companies' capabilities to access external funds).

\section{FINAL CONSIDERATIONS}

The present study aimed to test the empirical implications suggested by Almeida and Campello (2010) in Brazilian companies with respect to the effects of financial constraint and the resulting endogeneity of corporate investment in the light of the Pecking Order Theory's implications for the substitutivity between external and internal funds (i.e., this substitutivity is empirically linked to the negative relationship between 
cash flow and external funds). These authors suggest that if this negative relationship is larger in unconstrained than in constrained companies, it cannot be associated with the presence of costly external funds and cannot therefore be interpreted as evidence of behavior in accordance with the Pecking Order Theory.

The results from this study reveal that the sensitivity of external funds to cash flow is negative and statistically significant for the subsamples of both unconstrained and constrained companies. Additional results show that the external funds of the constrained companies present lower sensitivity to cash flow than those of the unconstrained companies. Finally, the internal funds of the constrained companies show a positive sensitivity to cash flow, whereas those of the unconstrained companies do not suggest significant and systematic behavior. The results were not susceptible to the econometric specifications and to the classification criteria.

These findings also maintain correspondence with the study of Almeida and Campello (2010). Thus, we can state that in companies subject to high external financing costs (constrained companies), the endogeneity of the investment makes internal and external funds more complementary than substitutive. This finding reasonably explains the behavior not explained by the Pecking Order Theory.

The present study also maintains theoretical correspondence with Khurana, Martin and Pereira's (2006) and Baum, Schäfer and Talavera's (2009) hypotheses that the positive sensitivity of internal funds to cash flow is conditioned by the financial system's structure and degree of development. The results of this study show that financial policies are more sensitive to cash flow among Brazilian companies than among US companies. This conclusion suggests that Brazilian companies invest greater effort into adjusting their financial policies to reduce the possibility of underinvestment.

This study helps to address the gap between capital structure theories and the behavior commonly reported in the literature as associated with the Pecking Order Theory and as contrary to the static trade-off theory: the negative relationship between cash flow and external funds. The fact that this study corroborates the evidence of Almeida and Campello (2010) indicates the explanatory inadequacy of these theories. The gap is addressed when the dynamic trade-off emerges as a theory with explanatory power regarding the behavior addressed in this study.

The dynamic trade-off theory explains how a negative relationship occurs between internal and external funds in unconstrained companies when, according to the arguments of Modigliani and Miller (1958), they should present indefinite behavior. According to the theory, the adjustment costs of capital structure can cause companies behaving optimally to not adjust their capital structures (i.e., maintain low debt levels) if the costs of adjusting the level of debt exceed the costs of maintaining a sub-optimal capital structure (Hennessy and Whited, 2005). In this direction, Strebulaev (2007) suggests that companies do not adjust their capital structures frequently because of market frictions.

In Brazil, studies involving dynamic trade-off are still incipient, but a few studies, such as those of Rocha and Amaral (2007) and Machado and Maia (2009), have presented evidence of the importance of adjustment costs in determining the capital structure. Similarly, no known studies in Brazil have explored the joint interaction between investments and funding decisions while considering the dynamic trade-off theoretical approach in an underinvestment risk context in the same manner as the international studies of Hennessy and Whited (2005) and Harford, Klasa and Walcott (2009). This study helps to fill this gap in the national literature.

Therefore, the present study contributes to the national literature on financial restrictions and capital structures. For analyses of financial constraints, this study contributes by successfully applying classification criteria concerning the degree of financial constraints to companies. Brazilian studies have found difficulties in establishing consistent classification criteria $a$ priori concerning the degree of financial constraints to companies (Aldrighi and Bisinha, 2010; Costa and Paz, 2004; Hamburger, 2004; Zani and Procianoy, 2005).

The present study also contributes to the understanding of how corporate and environmental characteristics affect companies' capabilities to meet their investment opportunities fully. In fact, the presence of financial frictions not only affects the real economy by quantitatively reducing investments but also changes the qualitative aspects of the investments (Almeida, Campello and Weisbach, 2011; Crisóstomo, 2009) if constrained companies prioritize investments with better payback and with the ability to generate collateral. Therefore, understanding corporate behavior in the face of financial frictions allows us to estimate more accurately the level and profile of the investments made by companies in the economy.

As a result, the present study contributes to a better understanding of how companies anticipate financial frictions by adjusting their financial policies (e.g., cash, debt, hedges and dividends). In turn, this improved knowledge allows for greater predictive capacity in models of corporate financial behavior. Likewise, it allows policymakers to develop institutional and financial instruments that make it possible to reduce the negative externalities of financial constraints. An example of such an instrument comes from one of the basic as- 
sumptions underlying the theoretical arguments of this study: net assets can be collateralized. For such assets to be collateralized, contractual covenants with adherents and effective enforcement are needed. According to Silva (2008), in Brazil, the imposition of these mechanisms has restricted applications to specific profiles of companies and credit operations.

References

Aldrighi, D. M., \& Bisinha, R. (2010, Janeiro-Março). Restrição financeira em empresas com ações negociadas na Bovespa. RBE, 64 (1), 25-47.

Almeida, H., \& Campello, M. (2007, April). Financial constraints, asset tangibility, and corporate investment. The Review of Financial Studies, 20 (5), 1429-1460.

Almeida, H., \& Campello, M. (2010, June). Financing frictions and the substitution between internal and external funds. Journal of Financial and Quantitative Analysis, 45 (3), 589-622.

Almeida, H., Campello, M., \& Weisbach, M. S. (2004). The cash flow sensitivity of cash. Journal of Finance, 59, 1777-1804.

Almeida, H., Campello, M., \& Weisbach, M. S. (2011). Corporate financial and investment policies when future financing is not frictionless. Journal of Corporate Finance, 17 (3) 675-693.

Bastos, D. D., Nakamura, W. T., \& Basso, L. F. C. (2009, NovembroDezembro). Determinantes da estrutura de capital das companhias abertas na América Latina: um estudo empírico considerando fatores macroeconômicos e institucionais. RAM, 10 (6).

Baum, C. F., Schäfer, D., \& Talavera, O. (2009, February). Impact of financial structure on firm's financial constraints: a cross-country analysis. Recuperado em 02 fevereiro, 2009, de http://www.ssrn.com/ abstract $=1431344$

Bekaert, G., \& Harvey, C. R. (2002, September). Research in emerging markets finance: looking to the future. Recuperado em 20 março, 2009, de http://www.papers.ssrn.com/sol3/ papers.cfm?abstract_id=795364.

Bernanke, B., \& Gertler, M. (1989). Agency cost, net worth, and business fluctuations. American Economic Review, 79 (1), 14-31.

Bruni, A. L. (2002). Globalização financeira, eficiência informacional e custo de capital: uma análise das emissões de ADRS brasileiros no período 1992-2001. Tese de doutorado, Departamento de Administração, Universidade de São Paulo, São Paulo, SP, Brasil.

Costa, C. M., \& Paz, L. S. (2004). Are Brazilian firms savings sensitive to cash windfalls? Anais do Encontro da Associação Nacional dos Centros de Pós-Graduação em Economia - ANPEC, João Pessoa, Niterói, RJ, XXXII.

Costa, C. M., Paz, L. S., \& Funchal, B. (March-August, 2008). Are Brazilian firms savings sensitive to cash windfalls? Brazilian Business Review, 5 (2), 136-142.

Crisóstomo, V. L. (2009, Maio-Agosto). Dificuldades das empresas brasileiras para financiar seus investimentos em capital físico e em inovação. Revista de Economia Contemporânea, 13 (2), 259-280.

Dittmar, A., Mahrt-Smith, J., \& Servaes, H. (2003). International Corporate Governance and Corporate Cash Holdings. Journal of Financial and Quantitative Analysis, 38, 111-134.

Erickson, T., \& Whited, T. M. (2000). Measurement Error and the Relationship between Investment and Q. Journal of Political Economy, 108 (5), 1027-1057.

Fama, E., \& French, K. (2002). Testing tradeoff and pecking order predictions about dividends and debt. Review of Financial Studies, 15, $1-33$.

Faulkender, M. (2002, March). Cash holding among small businesses. Recuperado em 01 dezembro, 2008, de http://www.papers.ssrn.com/ sol3/papers.cfm?abstract id $=305179$.

Faulkender, M., \& Wang, R. (2006). Corporate Financial Policy and the Value of Cash. Journal of Finance, 61, 1957-1990.

Fazzari, S. R., Hubbard, G., \& Petersen, B. (1988). Financing constraints and corporate investment. Brooking Papers on Economic Activity, 1, 141-195.

Fazzari, S. R., \& Petersen, B. (1993). Working capital and fixed investment: new evidence on financing constraints. RAND Journal of Economics, $24,328-342$

Frank, M., \& Goyal, V. (2003). Testing the pecking order theory of capital structure. Journal of Financial Economics, 67, 217-248.

Futema, M. S., Basso, L. F. C., \& Kayo, E. K. (2009). Estrutura de capital, dividendos e juros sobre o capital próprio: testes no Brasil. Revista Contabilidade \& Finanças, São Paulo: USP, 20 (49), 44-62.
Hamburger, R. R. (2004). O efeito da variação do fluxo de caixa nos investimentos corporativos no Brasil. Anais do Encontro Nacional dos Programas de Pós-Graduação em Administração - EnANPAD, São Paulo, Rio de Janeiro, RJ, IV.

Harford, J., Klasa, S., \& Walcott, N. (2009, July). Do firms have leverage target? Evidence from acquisitions. Journal of Financial Economics, 93 (1), 1-14.

Hennessy, C. A., \& Whited, T. M. (2005). Debt dynamics. Journal of Finance, 60 (3), 1129-1165.

Hubbard, R. G. (1998). Capital Market imperfections and investment. Journal of Economic Literature, 36, 193-227.

Iquiapaza, R. A., Lamounier, W. M., \& Amaral, H. F. (2008). Assimetria de informações e pagamento de dividendos na Bovespa. Advances in Scientific and Apllied Accounting, 1 (1), 1-15.

Jensen, M. (1986). Agency costs of free cash flow, corporate finance, and takeovers. American Economic Review, 76, 323-29.

Jensen, M. C., \& Meckling, W. H. (1976). Theory of the firm: managerial behavior, agency cost and ownership structure. Journal of Financial Economics, 3, 305-360.

Kalcheva, I., \& Lins, K. V. (2007). International evidence on cash holdings and expected managerial agency problems. Review of Financial Studies, 20, 1087-1112.

Khurana, I. K., Martin, X., \& Pereira, R. (2006, December). Financial development and the cash flow sensitivity of cash. Journal of Financial and Quantitative Analysis, 41 (4), 787-808.

Kiyotaki, N., \& Moore, J. (1997). Credit cycles. Journal of Political Economy, 105, 211-248.

Koshio, S., \& Cia, J. N. de S. (2004). The determinants of corporate cash holdings: a comparation between Brazilian and US firms. Anais do Encontro Brasileiro de Finanças - EBFin, São Paulo, IV.

La Porta, R., Lopez-de-Silanes, E., Shleifer, A., \& Vishny, R. (1998). Law and finance. Journal of Political Economy, 106, 1113-1155.

La Porta, R., Lopez-de-Silanes, F., Shleifer, A., \& Vishny, R. (1999). Legal determinants of external finance. Journal of Finance, 12, 1131-1150.

Leal, R. P. C. (2008, Outubro-Dezembro). Estrutura de capital comparada: Brasil e mercados emergentes. RAE, 48 (4), 67-78.

Machado, G. L. B., \& Maia, M. V. (2009). Custos de ajustamento e a dinâmica da estrutura de capital em empresas brasileiras. Anais do Encontro Brasileiro de Finanças - EBFin, São Paulo, IX.

Medeiros, O. R. de, \& Daher, C. E. (2008, Janeiro-Março). Testando teorias alternativas sobre estrutura de capital nas empresas brasileiras. RAC, $12(1), 177-199$.

Modigliani, F., \& Miller, M. H. (1958, June). The cost of capital, corporate finance and the theory of investment. American Economic Review, 48, 261-280.

Myers, S. C. The capital structure puzzle. (1984). Journal of Finance, 39, 575-592.

Myers, S. C., \& Majluf, N. S. (1984, June). Corporate financing and investment decisions when firms have information that investors do not have. Journal of Financial Economics, 13, 187-222.

Nakamura, W. T. et al. (2007, Maio-Agosto). Determinantes de estrutura de capital no mercado brasileiro - análise de regressão com painel de dados no período 1999-2003. Revista Contabilidade \& Finanças, 44, $72-85$.

Rocha, F. D., \& Amaral, H. F. (2007). A explicação da escolha da estrutura de capital por modelos de ajuste parcial: uma aplicação no Brasil. Anais do Encontro Nacional dos Programas de Pós-Graduação em Administração - EnANPAD, Rio de Janeiro, RJ, XXXI.

Shyam-Sunder, L., \& Myers, S. (1999). Testing static tradeoff against pecking order models of capital structure. Journal of Financial Economics, 51, 219-244.

Silva, A. H. C. (2008). Escolha de práticas contábeis no Brasil: uma análise sob a ótica da hipótese dos Covenants Contratuais. Tese de doutorado, Programa de Pós-Graduação em Ciências Contábeis, Universidade de São Paulo, São Paulo, SP, Brasil. 
Stigliz, J. E., \& Weiss, A. (1981, June). Credit rationing in market with imperfect information. The American Economic Review, 71 (3), 393410.

Strebulaev, I. A. (2007). Do tests of capital structure theory mean what they say? Journal of Finance, 62, 1747-1787.
Zani, J., \& Procianoy, J. L. (2005). Restrição financeira da firma: a variação na estocagem de liquidez determinada pelos status financeiro e pela geração de caixa operacional. Anais do Encontro Brasileiro de Finanças, São Paulo. 